\title{
Technology-Supported Models for Individuals with Autism Spectrum Disorder
}

\author{
https://doi.org/10.3991/ijet.v15i23.18791 \\ Beria Gokaydin $(\bowtie)$ \\ Near East University, Nicosia, Turkey \\ beria.gokaydin@neu.edu.tr
}

Anna V. Filippova

Plekhanov Russian University of Economics, Moscow, Russia

Natalia E. Sudakova

Moscow Academy of Professional Competencies, Moscow, Russia

Russian Presidential Academy of National Economy and Public Administration, Moscow, Russia

Victoriya V. Sadovaya

Kazan (Volga region) Federal University, Kazan, Russia

Irina V. Kochova

Financial University under the Government of the Russian Federation,

Moscow, Russia

Nigina S. Babieva

I. M. Sechenov First Moscow State Medical University (Sechenov University),

Moscow, Russia

\begin{abstract}
Autism can be defined as a common developmental disorder that manifests itself as a disconnection in social communication. In individuals with autism, sometimes speech does not develop at all, and even if it develops, the individual does not prefer to communicate by talking. Thus, other ways are needed to communicate with individuals with autism. Today, the most important of these ways is technology, especially educational technology. The use of technology for individuals with Autism spectrum disorder (ASD) is on the rise today. The purpose of this study was to present up-to-date information on research using technology-based intervention methods in teaching skills in different developmental areas to individuals from different age groups with ASD and to reveal whether this intervention method is effective. This study was carried out using qualitative research methodology, document analysis and related content analysis. Scopus is based on the analysis of published documents searched with the keywords 'autism and technology-based' in the database. All articles published in Scopus were examined. The distribution of affiliated universities by years, subject areas, document types, country/regions and author themes were examined. Various findings emerged in terms of determining the importance of the analysis of technology-supported applications in terms of
\end{abstract}


content of individuals published in the Scopus database on individuals with ASD. A total of 95 studies were examined. It was concluded that most of the studies were conducted in 2016 and 2019. It revealed that the first study was conducted in 2008. It was mostly published as a conference announcement. The United States and United Kingdom are among the countries with the most research. The research topics were written mostly in English, and two were published in French.

Keywords-Technology-based, autism, Scopus, content analysis, support education, special education

\section{Introduction}

Individuals with distinct differences compared to their peers are called disabled people. They are divided into groups according to the characteristics of their disability. In this research, we will consider the Autism disability group. Autism comes under the social-emotional development disability group. Autism can be defined as a pervasive developmental disorder that manifests itself as a disconnection in social communication. Autism spectrum disorder (ASD) is the most common type of developmental disability after mental disability, according to official figures. The United States of America (USA) is one of the countries where OIZ is seen most frequently. Therefore, the most comprehensive researches are carried out in the USA. In individuals with autism, sometimes speaking does not develop at all, and sometimes even if it does, they do not prefer to communicate by talking. In general, communication, cognitive and focusing problems of children diagnosed with ASD is a topic frequently mentioned in the literature [7,18]. Individuals with ASD have many characteristics. Inability to make eye contact, obsession with objects, inability to start and end a conversation and repetitive behaviours are the early symptoms of ASD. Understanding gestures, using body language, echolalia (use of stereotypical and repetitive verbal expressions), difficulties in language and communication skills, spontaneous initiation and maintenance of conversation, inadequacy in peer interaction and communication, limitations in sharing common interests and pleasure, interest in extraordinary topics, using objects for extraordinary purposes and excessive insistence against order and routines are among the main behavioural characteristics seen in individuals with $[1,2,4,8]$. Individuals with SB respond better to visual stimuli. The use of social stories together with technology to teach appropriate social skills and provide visual clues to individuals with ASD is an appropriate instructional approach [14]. All these problems negatively affect the teaching processes of children with ASD. One of the teaching approaches that will increase motivation in the teaching processes of individuals with ASD is technology-based teaching approaches.

With the development of technology day-by-day, teaching approaches have shifted from traditional teaching to modern education supported by technological equipment. The tools that are used effectively in the teaching process enable the subjects to be understood more meaningfully by students [16,26,29,31]. In the literature review, it was seen that positive results were obtained from computer-aided applications in the field 
of special education after the 2000s [3,17]. It was found that the best learning was directly proportional to how many sensory organs were affected. It was seen that the use of technology was used in the education of individuals with special needs, who differ from individuals with normal development, especially in terms of learning characteristics, as it is important to concretise abstract concepts. In many studies, it was stated that meaningful learning occured when the content was presented verbally and audio-visually in more than one form $[30,15,24,25]$. In short, it would be appropriate to say that the more sensory organs an individual uses in the learning process, the more effective learning takes place. In the field of special education, there are also opinions that the content designed by using multimedia is more attractive [5,6,32]. Digital technology-oriented tools attract the attention of students with ASD, and teaching in this way is often more effective [10,11,22,27]. The technological developments encourage the production of more informatics-based tools and software for individuals with developmental disabilities [20,21]. According to Sani Bozkurt [23] and Garzotto et al. [9], the possibilities provided by technology today are convenient for the use of social stories with new technologies. Social stories can be presented to individuals with ASD in different media, such as written, written-visual or video. Which environment or format to use is related to the developmental level and individual characteristics of the individual with ASD and what kind of social skills he/she needs [12].

When the literature on technology-based research in individuals with ASD was examined, it was seen that many skill areas were applied using computer-based instruction, smartphones and tablets. According to the reports of NAC and NPDC, technology-based interventions are scientifically based practices that are effectively used in the field of special education [33]. With the rapid development of technology and the increase in studies, it will be a guide for researchers and practitioners to examine the technology-based studies descriptively and interpret the results of the current studies on individuals with ASD. For this reason, it was decided to conduct this research. It is important in terms of revealing the studies conducted in the last years on individuals with ASD.

At the end of this research, autism and technology-based approaches were examined. Their distribution among countries, distribution between years, distribution between departments, distribution by place of publication and distribution according to published languages were also examined.

\subsection{The purpose and importance of the study}

The aim of this study is to systematically analyse the articles accessed through the search made in the Scopus database by examining them according to the selected themes and discussing them with other relevant basic concepts. Through research, researches on technology-based research conducted with the autism disability group were evaluated and contributions were made to studies in relevant subject areas. 


\section{Limitations}

- This research was limited to the selected and reviewed documents in the Scopus database.

- The research was limited to the documents published between the years 2008 and 2020.

- The content analysis of the documents was limited to the five themes specified above.

\section{$2 \quad$ Method}

This study was carried out using a qualitative research methodology, document analysis and related content analysis. The basic process in content analysis is to compile similar data within the framework of specified concepts and themes and to interpret organisations in a way that readers can understand. Content analysis is a scientific framework that enables a systematic analysis of written, oral and other sources. The research topics, the quality and quantity of the studies, the methods and the techniques used were evaluated by the content analysis method. Thus, it was seen that the trend in a certain area was likely determined. It is thought that the data obtained will make important contributions to the development of publishing policies of educational research, as well as directing educational research [19].

\subsection{Data collection and analysis}

Within the scope of the research of technology-based designs and teaching in individuals with autism, a research was conducted using the keywords 'autism and technology-based' in the Scopus database between 2008 and 2020, and 95 documents presented in the research were obtained. The documents obtained from the Scopus database were analysed, linked with each other and integrated, and the data were analysed by content analysis (Figure 1).

\section{5 document results}

TITLE-ABS-KEY ("autism" AND "technology based")

- Edit $\square$ Save $\triangle$ Set alert $ه$ Set feed

Fig. 1. The documents accessed on Scopus database through keywords 'autism and technology-based' 


\section{$3 \quad$ Findings}

\subsection{Distribution of documents by years}

At this stage of the research, the distribution of documents between the years 2008 and 2020 was examined. In this context, 95 studies were accessed through the Scopus database, and their distribution was presented in Table 1.

Table 1. Distribution of documents by years

\begin{tabular}{|c|c|}
\hline Years & Frequency \\
\hline 2020 & 10 \\
\hline 2019 & 22 \\
\hline 2018 & 11 \\
\hline 2017 & 8 \\
\hline 2016 & 17 \\
\hline 2015 & 8 \\
\hline 2014 & 3 \\
\hline 2013 & 6 \\
\hline 2012 & 2 \\
\hline 2011 & 4 \\
\hline 2010 & 1 \\
\hline 2009 & 2 \\
\hline 2008 & 1 \\
\hline
\end{tabular}

When we looked at autism and technology-supported studies, it was seen that the first study was conducted in 2008 from the distribution of studies by years. It was also found that most of the studies were conducted in 2019 (22) and in 2016 (17) and the least was conducted in 2008 (1) and 2010 (1).

\subsection{Distribution of documents by subject areas}

Table 2. Distribution of documents by subject areas

\begin{tabular}{|l|c|}
\hline \multicolumn{1}{|c|}{ Subject area } & f \\
\hline Computer Science & 37 \\
\hline Psychology & 35 \\
\hline Social Sciences & 25 \\
\hline Medicine & 24 \\
\hline Mathematics & 10 \\
\hline Arts and Humanities & 8 \\
\hline Engineering & 8 \\
\hline Health professions & 7 \\
\hline Neuroscience & 4 \\
\hline Biochemistry, Genetics and Molecular Biology & 2 \\
\hline Agricultural and Biological Sciences & 1 \\
\hline Chemical Engineering & 1 \\
\hline
\end{tabular}




\begin{tabular}{|l|l|}
\hline Energy & 1 \\
\hline Multidisciplinary & 1 \\
\hline Pharmacology, Toxicology and Pharmaceutics & 1 \\
\hline Physics and Astronomy & 1 \\
\hline
\end{tabular}

When we looked at autism and technology-based studies, it was seen that most of the studies were conducted in the field of Computer Science (37). It was seen that autism and technology-based studies focus on Psychology (35), Social Sciences (25) and Medicine (24).

\subsection{Distribution of documents by document types}

Table 3. Distribution of documents by document types

\begin{tabular}{|l|c|}
\hline \multicolumn{1}{|c|}{ Document types } & f \\
\hline Article & 48 \\
\hline Conference paper & 24 \\
\hline Review & 14 \\
\hline Book chapter & 3 \\
\hline Conference review & 2 \\
\hline Erratum & 2 \\
\hline Book & 1 \\
\hline Letter & 1 \\
\hline
\end{tabular}

When the document types of autism and technology-based studies were examined, it was seen that 48 studies were articles. It was found that 24 studies were presented as conference papers. However, there is one study each in Letter and Book document types.

\subsection{Distribution of documents by the countries of authors}

Table 4. Distribution of documents by the countries of authors

\begin{tabular}{|l|c|}
\hline \multicolumn{1}{|c|}{ Country } & f \\
\hline United States & 42 \\
\hline United Kingdom & 14 \\
\hline United States & 8 \\
\hline Australia & 7 \\
\hline China & 6 \\
\hline France & 4 \\
\hline India & 4 \\
\hline Spain & 3 \\
\hline Belgium & 3 \\
\hline Israel & 3 \\
\hline Malaysia & 2 \\
\hline Brazil & 2 \\
\hline Canada & 2 \\
\hline
\end{tabular}


Paper-Technology-Supported Models for Individuals with Autism Spectrum Disorder

\begin{tabular}{|l|c|}
\hline Germany & 2 \\
\hline Hungary & 2 \\
\hline Italy & 2 \\
\hline Netherlands & 2 \\
\hline Norway & 2 \\
\hline Romania & 2 \\
\hline
\end{tabular}

When the countries of the authors of the studies on autism with technology-based teaching were examined, it was revealed that the majority of the studies were conducted in the United States (42), followed by United Kingdom (14), Australia (8) and China (7).

There is one study each in Chile, Colombia, Finland, Hong Kong, Ireland, Pakistan, Portugal and Sweden. The countries of the authors of three studies are unknown.

\subsection{Distribution of documents by language}

Table 5. Distribution of documents by language

\begin{tabular}{|l|c|}
\hline \multicolumn{1}{|c|}{ Language } & f \\
\hline English & 93 \\
\hline French & 2 \\
\hline
\end{tabular}

When the studies published, by using the keywords technology-based teaching and autism, were examined, almost all of the studies were in English. Only two of them were published in French. There are no published studies in other languages.

\section{Conclusion and Discussion}

In the Scopus database, 5 topics were identified and 95 documents were reached, and the themes were determined as a content analysis initiated by the search with the keywords 'autism and technology-based".

Technology-based teaching and designs are rapidly increasing. Technology-based studies are of great importance when considering the effectiveness of the studies. With the rapid development of technology, many studies have been conducted on technology-based teaching on individuals with disabilities. In this study, autism and technology-based studies were investigated. Autism is a type of disability that has social problems and problems in terms of attachment, trust and communication skills. For this reason, autism and technology effectiveness are very important. In this context, with this study, the results of autism and technology-based teaching and designs indicate what the deficiencies are and what can be done. Autism and technology-based studies need to be increased. When we look at the autism and technology-supported studies conducted on individuals with autism, it was seen that the first study was conducted in 2008 from the distribution of studies by years. When we looked at the year 2008, when technology entered our lives, it was seen that the studies started late. It was determined that most of the studies were conducted in 2019 (22) and 2016 (17). It was concluded 
that the least studies were conducted in 2008 (1) and 2010 (1). Technological developments have encouraged the creation of more informatics-based tools and software for individuals with developmental disabilities [20,21]. Cognitive loading does not occur for individuals with ASD, but they can use these tools with an intuitive and exploratory approach. Another feature of these tools is that the communication allows not only touch-based communication but also the opportunity to present it to users with different approaches that enrich the content. It is the ability to increase functionality by communicating with the user (. For this reason, it can be said that studies on OIZ and technology-based teaching have increased in recent years.

By examining the autism and technology-based studies published in the Scopus database, it can be seen that most of the work was conducted in the field of Computer Science (37). Studies have also been conducted in the fields of Psychology (35), Social Sciences (25) and Medicine (24). In line with these results, the effects of technologybased teaching and designs on individuals with autism can be investigated in special education and other fields. In the past literature reviews of individuals with ASD, where technology-based intervention methods were provided, it can be seen that the literature generally focused on a specific skill area $[13,28]$. It can be seen that the literature focuses more on two areas. These areas are computer science and psychology. The reason why technology is related to computer science can be said to be related to the field of psychology as the psychological effects of the development of autism are intense. It can be said that it will be useful to expand the literature in different fields.

When autism and technology-based studies published in the Scopus database were examined, it was revealed that most of the studies were conducted in the United States of America (42), followed by the United Kingdom (14), Australia (8) and China (7). There are studies in Chile, Colombia, Finland, Hong Kong, Ireland, Pakistan, Portugal and Sweden. The countries of the three study authors are unknown. This result is not surprising when looking at the ranking of developed countries. Along with the technological developments used in developed countries, there are many studies in the field of autism. It can be suggested that research should be conducted on autism and technology-based studies in other countries. It can be said that autism and technologybased studies should be increased in Russia.

When the studies published in the Scopus database by searching the concepts of technology-based autism were examined, almost all of the studies were in English. Only two of them were published in French. There are no published studies in other languages. Studies can be published in terms of universality in other languages. Since English is the universal language in the world, it is not surprising that the languages of the articles published are in English. It may be suggested to publish studies in other languages.

\section{$5 \quad$ References}

[1] Abdi, M., \& Sharyati, A. (2019). Comparing the training effects of problem-solving and coping skills with stress. Global Journal of Psychology Research: New Trends and Issues, 9(1): 16-22. https://doi.org/10.18844/gipr.v9i1.4110 
[2] Attwood, T. (2000). Strategies for improving the social integration of children with Asperger syndrome. Autism, 4(1), 85-100. https://doi.org/10.1177/1362361300004001006

[3] Bhuyan, M., \& Tamir, A. (2020). Evaluating COs of computer programming course for OBE-based BSc in EEE program. International Journal of Learning and Teaching, 12(2), 86-99. https://doi.org/10.18844/ijlt.v12i2.4576

[4] Boyd, B. A., \& Shaw, E. (2010). Autism in the classroom: A group of students changing in population and presentation. Preventing School Failure, 54, 211-219. https://doi.org/10.10 $\underline{\text { 80/10459881003744552 }}$

[5] Carnahan, C., Basham, J., \& Musti-Rao, S. (2009). A low-technology strategy for increasing engagement of students with autism and significant learning needs. Exceptionality, 17, 7687. https://doi.org/10.1080/09362830902805798

[6] Carnahan, C., Musti-Rao, S., \& Bailey, J. (2009). Promoting active engagement in small group learning experiences for students with autism and significant learning needs. Education and Treatment of Children, 32(1), 37-61. https://doi.org/10.1353/etc.0.0047

[7] Diken, I. H. (2012). Turk annelerinin ve ozel gereksinimli cocuklarının etkilesimsel davranislarının arastirilmasi: erken mudahaleye yonelik oneriler (An exploration of interactional behaviors of Turkish mothers and their children with special needs: Implications for early intervention practices). Egitim ve Bilim, 37, 163.

[8] Fecteau, S., Mottron, L., Berthiaume, C., \& Burack, J. A. (2003). Developmental changes of autistic symptoms. Autism, 7(3), 255-268. https://doi.org/10.1177/13623613030073003

[9] Garzotto, F., Paolini, P., \& Sabiescu, A. (2010). Interactive storytelling for children. In Proceedings of the 9th International Conference on Interaction Design and Children (pp. 356-359). https://doi.org/10.1145/1810543.1810613

[10] Golan, O., \& Baron-Cohen, S. (2006). Systemizing empathy: Teaching adults with Asperger syndrome or high-functioning autism to recognize complex emotions using interactive multimedia. Development and Psychopathology, 18, 591-617. https://doi.org/ $10.1017 / \mathrm{s} 0954579406060305$

[11] Howlin, P., Baron-Cohen, S. J., \& Hadwin, J. (1999). Teaching children with autism to mind-read. John Wiley and Sons.

[12] Karkhaneh, M., Clark, B., Ospina, M. B., Seida, J. C., Smith, V., \& Hartling, L. (2010). Social Stories to improve social skills in children with autism spectrum disorder: A systematic review. Autism, 14(6), 641-662. https://doi.org/10.1177/1362361310373057

[13] Knight, V., McKissick, B. R., \& Saunders, A. (2013). A review of technology-based interventions to teach academic skills to students with autism spectrum disorder. Journal of Autism and Developmental Disorders, 43(11): 2628-2648. https://doi.org/10.1007/s10803013-1814-y

[14] Litras, S., Moore, D. W., \& Anderson, A. (2010). Using video self-modelled social stories to teach social skills to a young child with autism. Autism Research and Treatment, 2010, 1-9. https://doi.org/10.1155/2010/834979

[15] Mandl, H., \& Levin, J. R. (Eds.). (1989). Knowledge acquisition from text and pictures. Elsevier Science Publishers.

[16] Montaner, S. (2020). EFL written competence through twitter in mobile version in compulsory secondary education. Global Journal of Foreign Language Teaching, 10(2):101-110. https://doi.org/10.18844/giflt.v10i2.4665

[17] Nayak, S. \& Chandrakala, C. B. (2020). Assistive Mobile Application for Visually Impaired People. International Journal of Interactive Mobile Technologies (iJIM), 14(16): 52-69 https://doi.org/10.3991/ijim.v14i16.15295

[18] Newell, L. C., Best, C. A., Gastgeb, H., Rump, K. M., \& Strauss, M. S. (2010). The development of categorization and facial knowledge: Implications for the study of autism. Infant Perception and Cognition: Recent Advances, Emerging Theories, and Future Directions, 223-259. https://doi.org/10.1093/acprof:oso/9780195366709.003.0011 
[19] Olusum, B., \& Uzunboylu, H. (2017). Performance evaluation of schools: Content analysis of studies published between 1972 and 2017. International Journal of Educational Sciences, 19(2-3): 190-198. https://doi.org/10.1080/09751122.2017.1393963

[20] Ramdoss, S., Lang, R., Fragale, C., Britt, C., O’Reilly, M., \& Sigafoos, J. (2012). Use of computer-based interventions to promote daily living skills in individuals with intellectual disabilities: A systematic review. Journal of Developmental and Physical Disabilities, 24, 197-215. https://doi.org/10.1007/s10882-011-9259-8

[21] Ramdoss, S., Lang, R., Mulloy, A., Franco, J., O’Reilly, M., \& Didden, R. (2011). Use of computer-based interventions to improve communication in individuals with autism spectrum disorders: A systematic review. Journal of Behavioral Education, 20: 55-76. https://doi.org/10.1007/s10864-010-9112-7

[22] Gros, B. (2007). Digital games in education: The design of games-based learning environments. Journal of research on technology in education, 40(1): 23-38. https://doi. org/10.1080/15391523.2007.10782494

[23] Sani Bozkurt, S. (2016). Otizm spektrum bozuklugu olan cocuklara sosyal beceri ogretiminde teknoloji destekli etkilesimli ortam tasarimi ve etkililigi. https://doi.org/10.146 $\underline{\text { 86/buefad.v5i2.5000164182 }}$

[24] Schnotz, W. (1993). Introduction to special issue on comprehension of graphics in texts. Learning and Instruction, 3: 151-155. https://doi.org/10.1016/0959-4752(93)90007-M https://doi.org/10.1016/0959-4752(93)90001-g

[25] Schnotz, W., \& Kulhavy, R. W. (Eds.). (1994). Comprehension of graphics. North Holland/Elsevier Science Publishers.

[26] Poltisinsskaya, E., Lizunkov, V. \& Ergunova, O. (2019). Organization of Student Project Based Activities through Individual Learning Routes. International Journal of Emerging Technologies in Learning, 14(11): 186-193. https://doi.org/10.3991/ijet.v14i11.10312

[27] Van Eck, R. (2007). Building artificially intelligent learning games. In D. Gibson, C. Aldrich \& M. Prensky (Eds.), Games and simulations in online learning: Research and development Frameworks (pp. 271-307). Information Science. https://doi.org/10.4018/9 78-1-59904-304-3.ch014

[28] Wainer, A. L., \& Ingersoll, B. R. (2011). The use of innovative computer technology for teaching social communication to individuals with autism spectrum disorders. Research in Autism Spectrum Disorders, 5(1): 96-107. https://doi.org/10.1016/j.rasd.2010.08.002

[29] Wehmeyer, M. L., Palmer, S., Smith, S. J., Davies, D. K., \& Stock, S. E. (2008). The e icacy of technology use by people with intellectual disabilty: A single-subject design metaanalysis. Journal of Special Education Technology, 23, 21-30. https://doi.org/10.1177/0162 $\underline{64340802300303}$

[30] Willows, D. M., \& Houghton, H. A. (1987). The psychology of illustration. Springer-Verlag.

[31] Yehya, F. (2020). Promoting technology-implementation learning paradigm for online learning in secondary education. Global Journal of Information Technology: Emerging Technologies, 10(1): 12-21. https://doi.org/10.18844/gjit.v10i1.4620

[32] Kılınç, H., \& Fırat, M. (2017). Opinions of expert academicians on online data collection and voluntary participation in social sciences research. Educational Sciences: Theory \& Practice, 17(5). https://doi.org/10.12738/estp.2017.5.0261

[33] Yucesoy-Ozkan, Ş. (2015). Otizm spektrum bozuklugu olan bireyler icin bilimsel dayanakli uygulamalar. In A. Cavkaytar (Ed.), Otizm spektrum bozuklugu (pp. 125-160). Aile ve Sosyal Politikalar Bakanligi. https://doi.org/10.14527/9786053186342.10

\section{Authors}

Beria Gokaydin is a $\mathrm{PhD}$ candidate and lecturer in the Department of Special Education at the Near East University, North Cyprus. She teaches psychology, giftedness, individual 
differences in gifted education and inclusion courses. Her research interests include giftedness, gifted education, social and emotional problems of life with gifted individuals.

Anna V. Filippova is PhD in Law, Associate Professor of the Department of State-Legal and Criminal Law Disciplines at Plekhanov Russian University of Economics (36 Stremyannyi Pereulok, 115093, Moscow, Russia). She is a Russian scientist who has a scientific interest in the problems of law enforcement, legal education, and the application of educational technologies in the educational process with the participation of various categories of students. E-mail: Filippova.AV@rea.ru

Natalia E. Sudakova is a Doctor of Philosophy, Candidate of Pedagogy, 1) Director of the Institute of Pedagogy, Psychology and Philosophy of Education at the Moscow Academy of Professional Competencies (A29/33 Nizhegorodskaya Street, bldg. 15 109052, Moscow Russia); 2) Associate Professor of the UNESCO Chair at the Institute of Public Administration and Management at the Russian Presidential Academy of National Economy and Public Administration (84 Prospect Vernadskogo, bldg 2 119571, Moscow Russia). Her research interests are concentrated in the sphere of philosophy of inclusion, cultural anthropology, inclusive education and learning technologies. Email: sovetnik.imtp@mail.ru

Victoriya V. Sadovaya is $\mathrm{PhD}$ in Education, Associate Professor of the Department of Primary Education of the Institute of Psychology and Education at Kazan (Volga region) Federal University (18 Kremlyovskaya Street, 420000, Kazan, Russia). Her research interests are connected with the problems of educational environment, digitalization of the educational environment and students upbringing. She has more than 50 published papers in Russian journals and more than 20 published articles in International journals. E-mail: vikycha2006@mail.ru

Irina V. Kochova is PhD in Economics, Associate Professor of the Department of Psychology and Human Capital Development at Financial University under the Government of the Russian Federation (49 Leningradsky prospect, 125993, Moscow, Russia). Her main scientific and professional interests are related to psychological problems of personnel management, modern issues of changes in the labor market and employment issues. Actively studies regional labor markets. Strategy for the formation of human capital at the macro and micro levels, effective management and self-government. E-mail: Kokhova.ira@yandex.ru

Nigina S. Babieva is PhD in Psychology, Associate Professor of the Department of Nursing Management and Social Work of the Institute of Psychological and Social Work at the I. M. Sechenov First Moscow State Medical University of the Ministry of Health of the Russian Federation (Sechenov University) (119991, Moscow, Trubetskaya str., 8, p.2). Her main scientific and professional interests are related to the development of children with speech disorders. She is the head of the master's program in speech therapy. E-mail: $\underline{\text { n.s.babieva@mail.ru }}$

Article submitted 2020-09-23. Resubmitted 2020-10-08. Final acceptance 2020-10-09. Final version published as submitted by the authors. 